\title{
Pre-political Foundations of the Democratic Constitutional State - Europe and the Habermas-Ratzinger Debate
}

\author{
Pablo Cristóbal Jiménez Lobeira ${ }^{1}$
}

\begin{abstract}
In 2004 Jürgen Habermas and Joseph Ratzinger participated in a debate on the 'pre-political moral foundations of the free-state'. Their contributions showed broad agreement on the role of religion in today's Western secular state and on areas of collaboration and mutual enrichment between Modernity and Christianity in Europe and the West. They diverged regarding the need or not of a common cultural background prior to the existence of the polity. Their diverging point becomes all the more fascinating to the extent that the matter requires wider empirical, analytical and normative research before it can be settled. Nevertheless, the implications that derive from one or the other possibility are very different in terms, for instance, of immigration and citizenship policies. This is already clear in Europe and is becoming more evident in general in Western democracies.
\end{abstract}

Keywords: Christianity, Europe, Modernity, Muslim immigration, Prepolitical foundations, Western democracies

In January 2004 two prominent European intellectuals met for a discussion on the moral foundations of the constitutional state. One from the west (Düsseldorf, North-Rhine-Westphalia) and the other from the south (Marktl am Inn, Bavaria) of Germany, they both were born in the twenties and received their doctoral degrees in the sixties. Both have been leading thinkers in their respective fields. One of them represents the values of Enlightenment and secularism. The other one has been considered an icon of Christianity and religion.

The encounter has not been the only one either of them has had with thinkers of very contrasting extractions. Habermas was going to hold similar discussions with members of the Jesuit School of Philosophy in Münich. Ratzinger did likewise with Italian atheists Paolo Flores and Marcello Pera. Books would follow from each of those events (Habermas et al. 2010, Ratzinger \& Flores d'Arcais 2009, Ratzinger \& Pera 2006). As one could expect, strong contrasts appear between Habermas and Ratzinger. But surprisingly, they have coincidences and agreements too.

For Habermas, the democratic constitutional state is self sufficient in terms of the normative justification for its existence. It does not require more pre-political foundations than the legitimacy that its democratic constitution intrinsically 


\section{Pre-political Foundations, Democratic Constitutional State}

engenders. Its foundations are post-metaphysical.

In his perspective, what the state cannot generate through laws is the solidarity essential for its political life, for the participation of citizens in the making of laws and discussion of the common good of that society. The millenary religious traditions can be very useful to cover that lack. Yet in order to have those benefits potentially present in religions, the state must become neuter, and secularists should realise they are living in a post-secular age. Religious worldviews ought not to be discarded a priori as irrational, and secularism should be acknowledged as one more among different worldviews, giving way to a constructive dialog between secularists and believers.

For Ratzinger, the last fifty years have provided eloquent examples of laws that can be unjust, even when approved by overwhelming majorities. This opens the question - exemplified in the existence of a more or less widely accepted set of human rights - of whether legality is a synonym of legitimacy. And if laws - even democratic ones - are not the standard of justice, what is that standard, and who can give it?

According to him, religion has in the past been the pretext for wars and divisions in Europe, and in its fundamentalist forms is a motivation or at least an argument for terrorism today. On the other hand, enlightened, scientific reason has shown capacity not only for good, but also for new forms of destruction (atomic bombs) and manipulation of human beings (eugenics).

Both facts, he concludes, seem to indicate that religion and secularism, which in the case of the Enlightenment and Christianity share to a certain extent some common rationality and can work to balance and purify each other from their excesses. Christianity and Enlightenment could show, through a constructive relationship, the way of a process that other (non-'Western' - European) traditions (Islamic, Hindi, Chinese) might carry out in a similarly constructive manner with their respective forms of secularism (provided they have them). In this way the values and norms sensed by all human beings will eventually become more clearly recognised and used effectively in the world. Let us first delineate the problem both thinkers are trying to address.

\section{The problem of the normative foundations}

This was the central question of the debate: Is the political culture that allows the Western democratic constitutional state to work successfully, based on a moral background that is presupposed (and not explicitly acknowledged)? Jewish Professor of Law Joseph HH Weiler (not present in the debate) affirms:

One possible explanation for the success of what used to be called "Western Liberal Democracy" is precisely the Judaeo-Christian tradition, which persists in three ways...: one... Christianity taught us restraint in the relationship between Church and State as part of its religious self-understanding. "Render unto Caesar what is due to Caesar, render unto God what is due to God.” It may never claim the control over all aspects of life. It might have to say something about all aspects of life, but it acknowledges that there is a realm of politics where the Church may make demands, but does not pretend to rule. This is a discipline of self- restraint. The second one is more profound: The Judea-Christian tradition teaches 
self-restraint in our own exercise of our liberties. We are free to do many things, but we don't simply follow all our desires without restraint. We control our liberty in order to be truly free, which spills over into politics. Our political culture is a culture of self-restraint in the exercise of power, which - as even an atheist or agnostic would acknowledge - we owe to the Judeo-Christian tradition. Thirdly - and perhaps here the Judaic tradition has contributed even more than the Christian one - we uphold the idea of the rule of law. There is no democracy without the rule of law. This is the key to success (Weiler 2006).

Does this mean that Judeo-Christianity is the only or the best possible moral foundation for the political culture of an achieving liberal democracy, in contrast with other metaphysical traditions? Or that Judeo-Christianity happens to be the religious tradition of Europe and 'the West' and, because of that, it has worked well as the moral foundation for its democracies, but that successful liberal democracies could exist as well over different cultural backgrounds (Islam or Buddhism for instance)?

This paper seeks to answer neither of those questions ${ }^{2}$ that are in good part empirical ${ }^{3}$. It does have two goals in engaging with the contents of the debate: first, to advance in the analytical clarification of the problem; second, to enunciate some of the most important normative implications: if certain moral foundations are essential to a successful constitutional democracy, then those foundations ought to be kept and cherished not only in their intrinsic value for those citizens who hold them, but also due to their instrumental value as a source of cohesion and pre-political reference for the whole polity. Let us go through the contributions in the order in which they were made during the debate.

\section{A procedural foundation or sola ratio}

For Habermas the very doubt about the possibility of the constitutional democracy to renew from its own sources the normative presuppositions of its existence would be indeed 'an embarrassment to a state that was committed to neutrality in terms of its world view', following 'what Rawls has called "the fact of pluralism”' (Habermas \& Ratzinger 2006:21).

He admits that such consequence is not per se an argument against the existence of moral pre-political foundations, and passes to analyse the question from his Kantian, republican perspective ${ }^{4}$. He considers that Europe is entering into a 'post-secular' age - one of revival (or survival) of religion in 'secular' Europe (Casanova 2008). In Habermas’ own words,

(...) it is in the interest of the constitutional state to deal carefully with all the cultural sources that nourish its citizens' consciousness of norms and their solidarity. This awareness...is reflected in the phrase: "postsecular society"...[and] refers not only to the fact that religion is holding its own in an increasingly secular environment and that society must assume that religious fellowships will continue to exist for the foreseeable future. The expression "postsecular" does more than give public recognition to religious fellowships in view of the functional contribution they make to the reproduction of motivations and attitudes that are societally desirable. The public awareness of a post-secular society also reflects a normative insight that has consequences for the political dealings of unbelieving citizens with believing citizens. In the postsecular society, there is an increasing consensus 


\section{Pre-political Foundations, Democratic Constitutional State}

that certain phases of the "modernization of the public consciousness" involve the assimilation and the reflexive transformation of both religious and secular mentalities (Habermas \& Ratzinger 2006:46-7).

The state should acknowledge this fact for two reasons. First, so that the process of deliberation that brings about laws and debate in the public sphere will be legitimate and accepted by all. Second, because beyond formalities religious traditions might actually have something sensible to say regarding issues that concern the polity: 'philosophy has good reasons to be willing to learn from religious traditions' (Habermas \& Ratzinger 2006:42),

(...) not only for functional reasons, but also...for substantial reasons. This is because the mutual compenetration of Christianity and Greek metaphysics not only produced the intellectual form of theological dogmatics and hellenization of Christianity...[but] also promoted the assimilation by philosophy of genuinely Christian ideas. This work of assimilation has left its mark in normative conceptual clusters with a heavy weight of meaning, such as responsibility, autonomy, and justification; or history and remembering, new beginning, innovation, and return; or emancipation and fulfillment; or expropriation, internalization, and embodiment, individuality and fellowship (Habermas \& Ratzinger 2006:44).

An outstanding example is the concept, so enrooted in Western mentality, of human dignity and equality:

Philosophy has indeed transformed the original religious meaning of these terms, but without emptying them through a process of deflation and exhaustion. One such translation that salvages the substance of a term is the translation of the concept of "man in the image of God" into that of the identical dignity of all men that deserves unconditional respect. This goes beyond the borders of one particular religious fellowship and makes the substance of biblical concepts accessible to a general public that also includes those who have other faiths or who have none (Habermas \& Ratzinger 2006:44-45).

Habermas does not have any problem in acknowledging an important role for religion in the democratic constitutional state. As a secularist, he is moderate enough to differentiate between the political language which the polity uses to work (internal decision-making processes and policies) and the secular worldview which, as such, is comparable with the worldviews of other cultures and with religions:

The neutrality of the state authority on questions of world views guaranties the same ethical freedom for every citizen. This is incompatible with the political universalization of a secularist world view. When secularized citizens act in their role as citizens of the state, they must not deny in principle that religious images of the world have the potential to express truth. Nor must they refuse their believing fellow citizens the right to make contributions in a religious language to public debates. Indeed, a liberal political culture can expect that the secularized citizens play their part in the endeavors to translate relevant contributions from the religious language into a language that is accessible to the public as a whole (Habermas \& Ratzinger 2006:51-52).

But, does that mean that for Habermas a pre-political moral foundation, some cultural homogeneity in other terms, is required for the constitutional state to emerge? In his intervention, he dedicates the first part to explain why such 
moral foundation is not necessary, and the rest (four sections) to speak about the relation between secularism and religion in the state assuming it already exists and enjoys legitimacy and consistency on its own, without need of pre-political conditions. In his view,

\begin{abstract}
(...) "weak" suppositions about the normative contents of the communicative constitution of socio-cultural forms of life suffice to defend a non-decisionist concept of the validity of law both against the contextualism of a non-defeatist concept of reason and against legal positivism (Habermas \& Ratzinger 2006:25).
\end{abstract}

In other words, 'the constitution of the liberal state can satisfy its own need for legitimacy in a self-sufficient manner, that is, on the basis of the cognitive elements of a stock of arguments that are independent of religions and metaphysical traditions' (Habermas \& Ratzinger 2006:29). The aspect in which the constitutional state is not sufficient is that of motivation for citizens to be solidary to one another and to exercise other political virtues as for example active participation in the public sphere and voting $\stackrel{5}{5}$.

Habermas understands the foundations of the liberal state in a 'proceduralist' manner. He places his own position - 'deliberative democracy' - between liberalism and republicanism (Habermas 2006b:411). According to his understanding, inspired in Kant (as opposed to the Hegelian view of law), 'the basic principles of the constitution have an autonomous justification', rationally acceptable by all citizens (Habermas \& Ratzinger 2006:28).

If the democratic process is inclusive of all citizens who - through discourse express their opinions and engage in dialogue until they reach agreements, the results of that process will be rationally acceptable to all. At the same time, in order to be valid, the process must include the granting of basic liberal and political rights to all the members of the political community. The citizens, gathered in deliberation, give themselves a constitution, from which state authority emanates and which is subjected to the rule of law as its most inner core. Political power is totally permeated by the law. In the constitutional sate 'there is no ruling authority derived from something antecedent to the law' such as religion or some other fundament of its validity (Habermas \& Ratzinger 2006:26-7). Systems of law

...can be legitimated only in a self-referencial manner, that is, on the basis of legal procedures born of democratic procedures... If one sees them as a method whereby legitimacy is generated by legality, there is no "deficit of validity" that would need to be filled by the ethical dimension (Habermas \& Ratzinger 2006:27-8).

Though 'Christian theology' of 'the Middle Ages' and 'especially' the 'late Spanish Scholasticism' are present in the genealogy of human rights,

...[u]ltimately, however, the bases of legitimation of a state authority with a neutral world view are derived from the profane sources of the philosophy of the seventeenth and eighteenth centuries. It was only at a much later date that theology and the Church tackled the challenges of the revolutionary constitutional state. Nevertheless, if I have understood it correctly, the Catholic tradition, which is comfortable with the lumen naturale, has no problem in principle with an autonomous justification of morality and law (that is, a justification independent of the truths of revelation) [Habermas \& 


\title{
Pre-political Foundations, Democratic Constitutional State
}

\section{Ratzinger 2006:24-5].}

Thus the democratic constitutional state is self-sufficient or autonomous in terms of its justification. If a tradition had to be invoked as the basis for its understanding that would be mainly the Enlightenment (and only remotely Christianity). But that is only a question of sources, not of intrinsic requirements for a democratic constitutional state to exist and be legitimate.

What then becomes of Weiler's assertion that the success of 'Western liberal democracies' is owed in part to the moral substrate of Judeo-Christianity in them? Habermas seems to imply that no such tradition is necessary. Arguably, a political community with members of any cultural background could build a successful constitutional democracy, as long as they follow the procedures of discourse and deliberation.

This opens the possibility to create cosmopolitan, post-metaphysical, even 'post-national' states (a possible reading of European Union) where differences in worldviews are transcended and the political culture relies only on clear legal and discursive procedures. We will come back to this. First, though, let us turn to the other contribution to the debate.

\section{A moral foundation, or fides et ratio}

Ratzinger is not completely sure that a good procedure will suffice to ground a constitutional state. For him, politics must apply the criterion of the law to power, so that not the law of the stronger, but the strength of the law will hold sway. But applying the criterion of the law to power leads to a further question:

\begin{abstract}
How does law come into being, and what must be the characteristics of law if it is to be the vehicle of justice rather than the privilege of those who have the power to make this law? It is, on the one hand, the question of the genesis of the law, but, on the other hand, the question of its own inherent criteria. The problem that law must be, not the instrument of the power of a few, but the expression of the common interest of all, seems - at first sight to have been resolved through the instruments whereby a democratic will is formed in society, since all collaborate in the genesis of the law. This means that it is everyone's law. And as a sheer matter of fact, the guarantee of a shared collaboration in the elaboration of the law and in the just administration of power is the basic argument that speaks in favour of democracy as the most appropriate form of political order (Habermas \& Ratzinger 2006:58-59).
\end{abstract}

So far Ratzinger has followed the essential traits of Habermas' argument. But the problem is not solved:
And yet it seems to me that one question remains unanswered. Since total consensus among men is very hard to achieve, the process of forming a democratic will relies necessarily either on an act of delegation or else on a majority decision... But majorities, too, can be blind or unjust, as history teaches very plainly. When a majority (even if it is an utterly preponderant majority oppresses a religious or a racial minority by means of unjust laws, can we still speak in this instance of justice or, indeed, of law? (Habermas \& Ratzinger 2006:59-60).

There are indeed numerous examples in recent European history of laws and representatives that were approved democratically and held dubious ethical 
standards $\underline{6}$. So what is Ratzinger suggesting?

In other words, the majority principle always leaves open the question of the ethical foundations of the law. This is the question of whether there is something that can never become law but always remains injustice; or, to reverse this formulation, whether there is something that is of its very nature inalienably law, something that is antecedent to every majority decision and must be respected by all such decisions. The modern period has formulated a number of such normative elements in the various declarations of human rights and has withdrawn these from subjection to the vagaries of majorities. It is of course possible for the contemporary consciousness to be content with the inherent obviousness of these values... [which is, however,] by no means acknowledged in every culture. Islam has defined its own catalogue of human rights, which differs from the Western catalogue... And if my information is correct,...today's China...is asking whether "human rights" are merely a typically Western invention - and one that must be looked at critically (Habermas \& Ratzinger 2006:60-61).

He therefore points out to a moral foundation that precedes the law and that serves as criteria so that the law will always be just:

There are then, let us say, self-subsistent values that flow from the essence of what it is to be a man, and are therefore inviolable: no other man can infringe them... human rights... are incomprehensible without the presupposition that man qua man, thanks simply to his membership in the species "man", is the subject of rights and that his being bears within itself values and norms that must be discovered - but not invented. Today, we ought perhaps to amplify the doctrine of human rights with a doctrine of human obligations and of human limitations. This could help us grasp anew the relevance of the question of whether there might exist a rationality of nature and, hence, a rational law for man and for his existence in the world. And this dialogue would necessarily be intercultural today, both in its structure and in its interpretation (Habermas \& Ratzinger 2006:61, 71-72).

Why does that dialogue have to be 'intercultural' and not only Enlightened and Christian, since those two are 'the two great cultures of the West' which, each in its own way, have influenced the whole world? Because if it true that they claim to be de iure universal, de facto they are not (Habermas \& Ratzinger 2006:75). Western concepts of human rights, rule of law, separation of church and state, and others, have been born in specific cultural contexts that must be acknowledged and cannot be automatically reproduced in the whole of mankind (Habermas \& Ratzinger 2006:76).

To be sure, Ratzinger finds himself 'in broad agreement' with Habermas 'about the post-secular society, about the willingness to learn from each other, and about the self-limitation on both sides' - secular and religious rationalities. He speaks of 'pathologies in religion' which are extremely dangerous (terrorism, for example, often justified on religious grounds) and that make it necessary to see 'the divine light or reason as a "controlling organ"” (Habermas \& Ratzinger 2006:77). Religion 'must continually allow itself to be purified and structured by reason' (ibid).

At the same time, there are also 'pathologies of reason' with a hybris that is no less dangerous (atomic bombs and eugenics are also products of reason). Therefore 'reason, too, must be warned to keep within its proper limits, and it must learn a willingness to listen to the great religious traditions in mankind' 


\title{
Pre-political Foundations, Democratic Constitutional State
}

(Habermas \& Ratzinger 2006:78). Reason and faith, secularism and religion need each other to keep each other in balance, so to speak. In a global context:

\begin{abstract}
There can be no doubt that the two main partners in this mutual relatedness are the Christian faith and Western secular rationality; one can and must affirm this, without thereby succumbing to a false Eurocentrism. These two determine the situation of the world to an extent not matched by another cultural force; but this does not mean that one could dismiss the other cultures as a kind of quantité négligeable. For a western hubris of that kind, there would be a high price to pay - and, indeed, we are already paying a part of it... It is important to include the other cultures in the attempt at a polyphonic relatedness, in which they themselves are receptive to the essential complementarity of reason and faith, so that a universal process of purifications (in the plural!) can proceed (Habermas \& Ratzinger 2006:79).
\end{abstract}

He therefore is aware of the cultural diversity that is an evident fact, of all places, in today's Europe. At the same time he maintains that Europe and the West have at their cultural core both the Christian faith and the rationality of the Enlightenment.

\section{The normative foundations of the European polity}

The two visions are, in many ways, compatible with each other. Departing from different perspectives they reach common ground regarding the relations between secularism and religion. They differ, however, regarding the normative foundations of liberal democracies.

It becomes obvious how secular rationality and religious faith can 'purify', enrich and keep each other in balance within constituted states: religion accepts a secular political order, in which, however, it can aspire to be heard in the public sphere regarding visions of the common good, for example, as long as it translates its discourse into a language that everybody can understand. Secularism accepts that a 'neutral state' means an agnostic state, uncommitted to any worldview, which is not the same as 'anti-religious': at least some forms of secularism (laïcité) contain or can become themselves another worldview - and when that happens, it has no right to place itself above other, alternative worldviews (including those of religious traditions).

In their debate, both Habermas and Ratzinger attempt a theoretical analysis that as such overcomes contextual limitations. It is undeniable, however, that at the same time they move in a certain implicit (and sometimes explicit) background when they discuss the relations between secularism and religion. Both have as a reference, in the first place, the common Vaterland, inside which examples of the 'pathologies' either of religion or reason have happened at different points in history.

A second contextual circle is, if my reading is correct, 'Europe' (the European Union and surroundings). Europe has been the main arena of 'secularisation' first, and of 'post-secularisation' later: of Christianity and post-Christianity, Enlightenment and post-Enlightenment. Europe is today, as well, a place of cultural encounters brought about by the advent of massive immigration and the revival of the fastest growing religion in that region of the world: Islam. An encounter that has created new questions and challenges - empirical and 
theoretical - to Europe's former self-understanding as Christian, Modern - or both.

Such an experiment is being watched by the rest of 'the West' - that extension of cultural Europe present today in the United States, Canada, Australia and other countries outside geographical Europe. This is the third contextual circle.

The fourth would be the world, progressively more interconnected thanks to the development of globalisation. After all, Modernity and Christianity have expanded well beyond Europe.

So it may not be out of place to bring our problem (that of the normative foundations of the democratic constitutional state) to the context of the European project. The European Union is today a 'polity of sorts', analogical to constituted democracies (Jiménez 2010a): an impossible project for some, an uncompleted project for others, and still for others a new kind of polity.

The idea of elaborating a 'Constitution for Europe' (or constitutional treaty) was in part oriented to 'solve' such indeterminacy, tackle an increasing perception that the project lacked legitimacy, and find or create a citizens' feeling of belonging with the Union. That attempt however opened the Pandora's box of 'European identity', with a sharp debate around the Preamble (which in the cases of many constitutions makes references to the normative foundations of a polity, most constitutions of the EU member states included, Weiler 2003:53-84). What was the source of commonality for Europeans? Christianity and the Enlightenment?, a deliberative public sphere?, their 'social model'?, their international image as a 'normative power'?, or a cosmopolitan openness to diversity? (Jiménez 2010b).

For all the heated debate about the Preamble, the question was not resolved. Rather the Constitution was rejected no less than in pro-European, founding members, France and the Netherlands. What did became clear is that Europe as a polity is finding it hard to find or acknowledge its identity. And that such 'identity crisis' comes to the surface in the presence of the strong cultural force of Islam. That, at least, is Caldwell's (2009) thesis. If the cultural crisis of Europe springs to the surface before problems like immigration and refugee policy, criteria for expansion (especially to Turkey), integration of 'culturally diverse' citizens and residents, and resurgence of far-right parties in countries which up to recently were famous for their openness and tolerance (the Netherlands for example), Caldwell may have a point.

In places such as Europe today, the Habermas-Ratzinger debate acquires utmost relevance. A relevance not entirely insignificant for other parts of the West either. It is against this background that I would like to submit some thoughts as points of departure for further research.

First a word about Habermas' idea of the intercourse between secularism and religion in the public sphere. Though the model itself is under discussion in its many nuances, especially in the presence of a number of different cultures in liberal societies, its principles appear as very sound. 'Secularism' as a way to order the political community from an agnostic perspective promises the best 


\section{Pre-political Foundations, Democratic Constitutional State}

arrangement known in order to make a democratic state work. 'Secularism' as a worldview (laïcité) deserves a place in the public sphere, at the side of other worldviews (religious or not), but does not have a right to claim a 'monopoly of culture' that excludes other worldviews from the public sphere.

Ratzinger cannot but endorse this view, only expounding on its usefulness to 'purify' and keep in check what in Europe and the West have been so far the core cultural traditions, namely Modernity and Christianity. There are examples on how religions can and indeed have participated in the public sphere as part of civil societies.

The Catholic Church, for one, has attempted to contribute to public discussion ${ }^{7}$ in the last 120 years through papal 'encyclical letters' and other official Vatican documents starting from Leo XIII's (1893) Rerum novarum (on the condition of labour) until Benedict XVI's (2009) Charitas in veritate (on integral development), including a Compendium of the Social Doctrine of the Church that came out in 2004. According to George Weigel (2003) the Catholic 'social doctrine' can be summarised in four principles: personalism or the human rights principle, which places the 'inalienable dignity and value of the human person' as foundation of its understanding of politics and society; the principle of common good (or communitarian principle); the principle of subsidiarity or of civil society; and the principle of solidarity or of civic friendship (Weigel 2003:17-18).

Other Christian churches participate in their own way - Evangelicals for example as a prominent example in United States, Anglicans in the United Kingdom and Australia, Orthodox in Eastern Europe, and so on -, not to speak of the Jewish, Muslim, Buddhist ${ }^{\circledR}$, Hindu, Confucianist and other traditions. Cultural and religious traditions have a lot to contribute to society through participation in the public sphere. They can be sources of wisdom and solidarity among citizens. An awareness of this could help Europe to deal with its immigration, especially when the newcomers possess a strong religious identity as is the case of Muslims.

Second thought. Does the constitutional democratic state need moral prepolitical foundations, a cultural background of some kind, common to all citizens, that allows the polity to work or is the procedure that ensures success? This is an empirical question that cannot be answered here. Some accounts seem to suggest that there is a relationship between certain cultural backgrounds and the development of successful liberal democracies.

Caldwell (2009:159) affirms that 'European secularism is set up with Christians in mind. The concepts that arise out of Muslim communities are not identical'. Huntington (2004) considers Christianity (especially under its Protestant banner) an essential foundation of United States as a nation and responsible, together with its English background, of its success as a democracy..$^{-}$Molony (2005) mentions Christianity - both in its Anglican and its Catholic branches - as part of the cultural and moral foundations of Australia. And so does Bothwell (2006) for the case of Canada. Virtually all member states in the European Union have Christianity as a strong component of their culture, regardless of the number of active adherents (Caldwell 2009). 
Habermas himself, though in explicit disagreement against the idea that the constitutional state needs any pre-political cultural common ground, cannot avoid to mention the 'springs that well forth spontaneously - springs that one may term "pre-political”, found in civil society in which citizens are embedded. Those pre- political energies motivate citizens to care not only about their own individual interests, but also about the common good, and to practice the political virtues that are 'essential if a democracy is to exist' (Habermas \& Ratzinger 2006:30-31). Even the very conception Habermas has of constitutional patriotism is not completely free of cultural backgrounds:

\begin{abstract}
Despite a very common misunderstanding, "patriotism linked to the constitution" means that the citizens wholeheartedly accept the principles of the constitution, not only in their abstract substance, but very specifically out of the historical context of the history of each nation. The cognitive process on its own does not suffice, if the moral substance of basic rights is to conquer the people's attitudes... An abstract solidarity, mediated by the law, arises among citizens only when the principles of justice have penetrated more deeply into the complex of ethical orientations in a given culture (Habermas \& Ratzinger 2006:33-34).
\end{abstract}

Of course, the question here is whether the values of the Enlightenment are universal (therefore agreeable with potentially any cultural background) or if they cannot be understood without the particular cultural background from which they emerged. Admittedly, even if it can be shown that they emerged from a specific cultural background, the conceptual possibility that they agree with different cultures remains. This was Benazir Bhutto's (2008:17-80) claim regarding her religion, Islam, as committed 'not only to tolerance and equality but to the principles of democracy ${ }^{10}$.

But if it is true that the most advanced liberal democracies in the world - United States, those in Western Europe, Canada or Australia for instance - do have a pre-political component that everybody takes for granted (and therefore nobody mentions explicitly) and informs the laws and the political life of the country, then there is a strong case for that component to be investigated, specified, acknowledged and preserved if liberal constitutional democracies wish to continue to be $\operatorname{such}^{11}$.

Western polities ought to open discussion about the culture that underlies their beginnings and that has allowed them to become successful democracies. Once they are recognised, they should make sure newcomers, even (or especially?) those with different cultural backgrounds, learn about those values when they arrive.

Successful liberal democracies should be as open, tolerant and inclusive, as their fundamental political core - and the culture sustaining it - is not broken. In other words, they should not compromise their existence as successful liberal democracies. This does not mean exclusion: it means clarity (for survival). Some might see it as a sign of cultural arrogance: some others might see it as a requirement of fairness to the 'natives' as well as to the newcomers - to the natives, so that what they have built through generations can be kept; to the newcomers, so that the benefits they are seeking when they immigrate continue to exist. 


\title{
Pre-political Foundations, Democratic Constitutional State
}

This in Europe may mean, first of all, acknowledging the place of Judeo-Christianity in its history and culture, something tremendously difficult to do for the political class, if judged by the denial to even mention 'God' or 'Christianity' in the preamble of the constitutional treaty, when similar words or even phrases exist in many constitutions of the member states (Weiler 2003:53-84). Less contested is, at least for the moment, the cultural place of Modernity - the values of the Enlightenment - in the political culture of Europe ${ }^{12}$.

As citizens whose cultural background rests on Islam and other religions find explicit definition of the values that have made Europe what it is today and are happy to abide by them, they, in turn, will be able to influence Europe's public life through their participation in the public sphere. Muslim Europeans might have a slightly different opinion on their conception of Europe, if the ideas of spiritual leaders such as Yusuf Al-Qaradawi ${ }^{13}$ (2010) are representative of their views:

\begin{abstract}
Secularism may be accepted in a Christian society but it can never enjoy a general acceptance in an Islamic society. Christianity is devoid of a shari 'ah or a comprehensive system of life to which its adherents should be committed. The New Testament itself divides life into two parts: one for God, or religion, the other for Caesar, or the state: "Render unto Caesar things which belong to Caesar, and render unto God things which belong to God" (Matthew 22:21). As such, a Christian could accept secularism without any qualms of conscience (...) For Muslim societies, the acceptance of secularism means something totally different; i.e. as Islam is a comprehensive system of worship ( `ibadah) and legislation (Shari `ah), the acceptance of secularism means abandonment of Shari ah, a denial of the divine guidance and a rejection of Allah's injunctions; It is indeed a false claim that Shariah is not proper to the requirements of the present age. The acceptance of a legislation formulated by humans means a preference of the humans' limited knowledge and experiences to the divine guidance: "Say! Do you know better than Allah?" (2:140).
\end{abstract}

If and when they become the majority of the population in Europe they will have the numbers (democratic majority) for a re-thinking of values and the corresponding re-shaping of the European polity. Meanwhile, acknowledgement by native Europeans (and natives in other Western democracies for that matter $)^{14}$ of what has allowed them to be what they are today does not mean that they can not be open to immigration with different cultural backgrounds. It only means that they will carry out that process, first of all, knowing what their own culture is; and secondly, what elements in their own culture are essential and which ones are dispensable in order to maintain successful democratic polities $\underline{\underline{15}}$. This might then have effects not just on immigration and refugee policies, but also on the ones addressed at the integration of residents in the changing political community - European citizenship among them.

Whether the constitutional state can be born and derive its legitimacy based only on procedures and deliberation (to put it simply, 'culture- free') is still open to debate. Certainly the procedures themselves can rely upon rules (the law) and a defined form of participation (citizenship). At the same time, both the rules and the citizens spring from a cultural context. The link between 'Western' cultural background and successful liberal democracies can not be discarded as irrelevant and ought to be explored. Such 'background' includes not only the 
Enlightenment, but also the Judeo-Christian humus from which (and against which) it sprung. This investigation will in turn shed light and ideas on how the Western democratic constitutional state can approach and accommodate citizens with strong and diverse cultural backgrounds.

\section{References}

Al-Qaradawi, Yusuf (2010) ‘Secularism v Islam’ In How the Imported Solutions Disastrously Affected Our Ummah pp. 113-4 Accessed June 2010 http://islamicweb.com/beliefs/cults/Secularism.htm

Australian Citizenship- Our Common Bond (2009) National Communications Branch, Department of Immigration and Citizenship, Australian Government, Belconnen, ACT

Bhutto, Benazir (2008) Reconciliation - Islam, Democracy and the West Harper Collins, New York

Bothwell, Robert (2006) The Penguin History of Canada Penguin Toronto Caldwell, Christopher (2009) Reflections on the Revolution in Europe. Can Europe Be the Same with Different People in It? Penguin, London

Casanova, José (2008) ‘Public Religions Revisited’ in: Hent de Vries (ed) Religion: Beyond the Concept, Fordham University Press, pp. 101-119

DFAT (2006) 'Muslims in Australia' Department of Foreign Affairs and Trade, Australian Government, Viewed 5 July 2010: http://www.dfat.gov.au/facts/muslims in australia.html

Habermas et al. (2010) An Awareness of What is Missing - Faith and Reason in a Post-Secular Age Polity Press, Cambridge

Habermas, J \& Derrida, J (2003) 'February 15, or what binds Europeans together: a plea for a common foreign policy, beginning in the core of Europe' Constellations Vol. 10, No. 3

Habermas, J \& Mendieta, E (2010) 'A Postsecular World Society? - On the Philosophical Significance of Postsecular Consciousness and the Multicultural World Society' (interview with Habermas by Mendieta, translated from the German by Matthias Fritsch) Blog The Immanent Frame-Secularism, religion and the public sphere Accessed June 2010:

http://blogs.ssrc.org/tif/2010/02/03/a-postsecular-world-society/

Habermas, J \& Ratzinger, J (2006) Dialectics of Secularization - On Reason and Religion (translated by Brian McNeil) Ignatius, San Francisco Habermas, Jürgen (2001b) The Post-national Constellation. Political Essays (translated and edited by Max Pensky). MIT Press. Cambridge, Massachusetts

Habermas, Jürgen (2001c) 'Why Europe Needs a Constitution' New Left Review 11, Sep-Oct 2001:5-26

Habermas, Jürgen (2003) 'Making sense of the EU: Toward a Cosmopolitan Europe’ Journal of Democracy 14 (4):86-100

Habermas, Jürgen (2004) La inclusión del otro ('the inclusion of the other', translated from German to Spanish by Juan Carlos Velasco Arroyo) Paidós Básica, Barcelona

Habermas, Jürgen (2005) 'Equal Treatment of Cultures and the Limits of 


\section{Pre-political Foundations, Democratic Constitutional State}

Postmodern Liberalism' (translated by Jeffrey Flynn) The Journal of Political Philosophy 13 (1):1-28

Habermas, Jürgen (2006a) 'Religion in the Public Sphere' European Journal of Philosophy’ Vol. 14, Issue 1, pp. 1-25

Habermas, Jürgen (2006b) 'Political Communication in Media Society: Does Democracy Still Enjoy an Epistemic Dimension? The Impact of Normative Theory on Empirical Research' Communication Theory 16:411-426

Huntington, Samuel (2004) Who are We? Simon \& Schuster, New York Jiménez, Pablo (2010a) 'Exploring Cosmopolitan Communitarianist EU

Citizenship-An Analogical Reading' (June 5, 2010).

Available at SSRN: http://ssrn.com/abstract=1620882

Jiménez, Pablo (2010b) 'Towards a Notion of European Political Identity' (June

16) 17th Annual Australian Association of Professional and Applied Ethics

Conference, University of Sydney, Austraila. Available at SSRN: http://ssrn.com/abstract=1626054

Molony, John (2005) Australia, Our Heritage. A History of a Nation Australian Scholarly Publishing Pty Ltd Canberra

Neighbour, Sally (2010a) 'Extremists with caliphate on their minds, not bombs in their belts' The Australian (3 July, 12 am) Viewed 3 July 2010: http://www.theaustralian.com.au/news/world/extremists-with-caliphate-o $\underline{\text { n- their-minds-not-bombs-in-their-belts/story-e6frg6ux-1225887074605 }}$

Neighbour, Sally (2010a) 'Muslims told to shun democracy' The Australian (5 July, 12 am) Viewed 5 July 2010: http://www.theaustralian.com.au/news/nation/islamic-hardliners-return-f or-

sydney-convention-after-push-for-ban-fails/story-e6frg6nf-1225887315042

Ratzinger, J \& Flores d'Arcais, P (2009) Dios, ¿existe? ('Does God exist?', translated from the Italian into Spanish by Carmen Bas Álvarez \& Alejandro Pradera Sánchez), Espasa-Calpe, México

Ratzinger, J \& Pera, M (2006) Without Roots - The West, Relativism, Christianity, Islam (translated from the Italian by Micahel F Moore) Basic Books, New York

Ratzinger, Joseph (2004) Truth and Tolerance - Christian Belief and World Religions (translated by Henry Taylor) Ignatius, San Francisco

Spiegel Online (2005) ‘God Has Disappeared’ Interview with Al-Jazeera Host Yusuf Al-Qaradawi by Volkhard Windfuhr and Bernhard Zand, 9 of September. Accessed June 2010 at http://www.spiegel.de/international/0,1518,376954,00.html

The Economist Intelligence Unity (2008) 'Democracy Index’ Accessed June 2010: http://a330.g.akamai.net/7/330/25828/20081021195552/graphics.eiu.com/ PDF/Democracy\%20Index\%202008.pdf

Weigel, George (2003) 'The Church’s Social Doctrine in the Twenty-First Century' Logos 6 (2) Spring, Accessed July 2010: http://muse.jhu.edu/journals/logos/toc/log6.2.html

Weiler, JHH (2003) Un’Europa cristiana - Un saggio esplorativo ('A Christian Europe - an Exploratory Essay) BUR Milano

Weiler, JHH (2006) 'Europe’s Struggle with Itself - Perspectives from a Wandering Jew’ Letter for Europe 9 (July) Viewed November 2009 


\section{http://www.europe4christ.net/index.php?id=54\&no cache=1}

\section{Endnotes}

${ }^{1}$ Centre for European Studies \& Centre for Applied Philosophy and Public Ethics - Australian National University

${ }^{2}$ For an interesting study in comparative religions dealing with these problems see Ratzinger (2004).

${ }^{3}$ I have not seen studies focusing directly on this issue. The 'Democracy Index' 2008' elaborated by The Economist Intelligence Unity classified as 'full democracies' thirty countries. With the exception of Japan, and partially of Mauritius and South Korea (both around 30\% Christian), the other 27 countries have a Christian background. Clearly, many countries with Christian background were not in that list. If we believe this study it would appear that Christianity is, therefore, neither a necessary nor a sufficient condition, though one likely to help a good outcome. This matter has to be further explored empirically, analytically and normatively.

${ }^{4}$ Which he explains in more detail in Habermas (2004).

${ }^{5} \mathrm{He}$ assumes that voting cannot be compulsory, as is the case in Australia.

${ }^{6}$ The Nürenberg trials might be one.

${ }^{7}$ Often addressed not only to adherents, but also 'to all man of goodwill'.

${ }^{8}$ In Burma and Tibet for example.

${ }^{9}$ One does not need to endorse Huntington's 'clash of civilisations' approach to consider seriously his analysis.

${ }^{10}$ For all her effort to promote mutual knowledge and understanding between Islam and the West, she was aware of a battle for 'the hearts and soul of Islam....between moderates and fanatics, between democrats and dictators, between those who live in the past and those who adapt to the present and plan for a better future' (Bhutto, 2008:19-20). For her 'in the resolution of this conflict may in fact lie the direction of international peace in the twenty-first century' (Bhutto 2008:20). Unfortunately she did not live to see these developments. Extremists attempted (unsuccessfully) to assassinate her in October 2007 - 179 people died - and successfully in December 2007 - together with at least another 23 persons.

${ }^{11}$ Recognition of this cultural background would not necessarily imply that other potentially compatible combinations could be explored, for example between Islam and constitutional democratic values, as Bhutto and others have attempted.

${ }^{12}$ There is of course a clear push towards 'post-modernity' and 'post-secularity' but that has not undermined yet some general consensus about 'modern values' in liberal democracy. For interesting comments on this subject see Habermas \& Mendieta (2010).

${ }^{13}$ According to Der Spiegel, 'one of the most influential contemporary Muslim scholars'. Through his Al- Jazeera talk show, 'Sharia and Life' along with his Web site Islam Online he reaches millions of people throughout the Muslim world. He is also a leading figure for millions of Muslims in Europe (Spiegel Online 2005).

${ }^{14}$ Today Australia has a Muslim population of around 2\% according to figures of the Australian Government (DFAT 2006). The Australian (Neighbour 2010a) reported a few days ago an interview with Uthman Badar, spokesman of the Islamic organisation Hizb ut-Tahrir. According to Badar, Western democracy - now in fight with Islam - will collapse (as happened with the communist world). During a Hizb ut-Tahrir conference on the $4^{\text {th }}$ of July held in Sydney, British Islamist leader Burhan Hanif recommended Australian Muslims to shun secular democracy (Neighbour 2010b).

${ }^{15}$ The Australian citizenship test (Australian Citizenship, Our Common Bond 2009:4), for instance, is 'designed to assess whether' applicants 'have an adequate knowledge of Australia', of 'the responsibilities and privileges of citizenship' and of English, the 'national language'. It teaches newcomers that Australia has a secular government, 'a Judeo-Christian heritage', and that 'people in Australia are free to follow any religion they choose' or 'to not follow a religion' (Australian Citizenship, 